\title{
GEOGRAFIE EN SY VERHOUDING TOT BEPLANNING*
}

As die geografie hom besig hou met die studie van die aarde as woonplek van die mens, soos die meeste geograwe waarskynlik aanvaar, is dit logies dat die klem in die vak van tyd tot tyd sal verskuif namate die mens se tegnologiese vordering enersyds verandering aanbring in die onderlinge verhoudings van die samestellende dele van die menslike omgewing, en andersyds in die steeds veranderende wyse waarop die mens die aarde bewoon.

So 'n klemverskuiwing in die geografie het al meermale in die verlede voorgekom, en dit is die oogmerk om in hierdie betoog die standpunt te motiveer dat die geografie juis nou weer te doen het met die behoefte aan so 'n klemverskuiwing.

Om dit te kan doen, moet daar eerstens aangestip word watter groot veranderinge in die verlede in die benadering van die geografie voorgekom het; tweedens moet aangedui word hoe die verhouding tussen die mens en sy woonplek as gevolg van die tegnologiese vooruitgang verander het; derdens moet kortliks gelet word op die pogings wat aangewend is om die verandering in hierdie verhouding te begryp en te rig; en in die laaste instansie moet dan gevra word watter bydrae die geografie as verhoudingswetenskap kan aanbied om die ewewig in die verhouding tussen die mens en sy omgewing te bewaar of, as dit versteur is, te help herstel.

\section{Klemverskuiwings in die geografie}

Om die vroegste kenmerke van die geografie as wetenskap te begryp, moet ' $n$ mens in die verbeelding terug gaan na die antieke wêreld sonder langafstandkommunikasie, massamediums of meetinstrumente. Die bronne van kennis was meestal oorlewering, dikwels tweede- of derdehands of selfs meer, en uit hierdie beperkte bronne moes die geograaf voorsien in die „wyd verspreide behoefte van baie mense om te weet hoe ander dele van die wêreld lyk" $(16: 130)$. Die studieveld van die vak het feitlik die hele heelal behels, en baie vakke wat vandag selfstandige wetenskappe is, was bloot onderdele van die geografie.

* Inougurele rede, gelewer op 4 Aug. 1967, by die aanvaarding van 'n professoraat in Aardrykskunde en Beplanning, aan die P.U. vir C.H.O. 
Dit was die hooftaak van die geografie om die woonplek van die mens chorologies te beskryf namate meer kennis van afgeleë gebiede en nuwe vastelande beskikbaar word. Die optrede van mense soos Alexander die Grote wat dikwels nie geografiese motiewe gehad het nie, het hierdie beskrywingstaak aangehelp deur die beskikbaarstelling van nuwe materiaal, en namate minder onontdekte dele van die aarde oorgebly het, het hierdie aspek van die taak van die geografie in belangrikheid afgeneem. Weliswaar is dit vandag na meer as twee millenniums nog nie voltooi nie - Antarktika bied byvoorbeeld nog ' $n$ wye veld vir geografiese beskrywing, gletsers in ontoeganklike berggebiede word nog ontdek en slegs enkele jare gelede is die eerste keer verneem van die ondersese berg Vema met sy groot ekonomiese moontlikhede nie ver van Suid-Afrika se kus af nie - maar hierdie aspek van die geografie het nogtans steeds minder belangrik geword.

Intussen het ook ander rigtings wat voorheen as onderdele van die geografie beskou is as selfstandige wetenskappe ontwikkel. In hierdie opsig het die geografie dus ook in sy omvang gekrimp $(2: 2)$. Dié omstandighede het die gedagte by sommige laat ontstaan dat al die onontdekte dele van die aarde nou bekend is, dat die geografie as navorsingsdissipline uitgedien is, en dat daar niks meer vir geograwe oorbly om te doen as om die vak aan ander te doseer nie $(17: 15)$. Daar was selfs ' $n$ stadium in die eerste helfte van die vorige eeu toe die geografie nie langer as selfstandige wetenskaplike dissipline beskou is nie maar slegs as hulpmiddel by die studie van die geskiedenis en die administrasie van die staat $(8: 6)$.

\section{Van beskrywing na verklaring}

Dit is die twee groot Duitse tydgenote, Alexander von Humboldt en Carl Ritter, wat in die eerste helfte van die negentiende eeu verantwoordelik was vir die eerste groot klemverskuiwing in die geografie. Vir hulle moes die geografie nie bloot toevallig naas mekaar bestaande oppervlakverskynsels beskryf nie; dié verskynsels moet gesien word as onderling verbonde, en die verbondenheid moes verklaar word $(8: 7)$. Van beskrywing word in hierdie stadium dus oorgegaan tot verklaring en die toon vir die nuwe gedragslyn word aangegee deur Von Humboldt se stelling dat, selfs al is die volledige doelwit onbereikbaar, die hoogste strewe van alle 
navorsing steeds moet bly 'n begrip van die wêreldverskynsels $(15: 162)$. 'n Fase word betree waarin oorsaak en gevolg die oogmerk van geografiese navorsing word (17:17).

Die probleem om verskynsels wat oor die hele aardbol voorkom in hanteerbare groeperings te kry, word opgelos deur die streeksbegrip as geografiese instrument in te voer sodat ooreenkomste en verskille bespreek kan word by wyse van vergelyking van sogenaamde geografiese streke in plaas van politieke eenhede. Die geografie betree sodoende 'n stadium waarin sy vernaamste probleem beskryf kan word as dié van ruimtelike differensiasie. Hierdie uitgangspunt blyk egter ook nie sonder sy probleme te wees nie. Daar is enersyds gevoel dat dit lei tot ' $n$ stagnante resultaat: by sy logiese uiteinde beklemtoon dit 'n hiërargie van streke as die eintlike probleem van die geografie. Maar selfs al was hierdie antiklimaks nie daar nie, bied die metodes van ruimtelike differensiasie baie selde aansluiting by die werk van ander wetenskappe waarmee die geografie noue verband handhaaf $(1: 434)$. Probleme van organisasie en funksie is op die agtergrond geskuif ten gunste van wat neerhalend genoem is ' $n$ oefening in die klassifikasie van gebiede, en daar is nie met dié metode daarin geslaag om ' $n$ analitiese middel te ontwerp wat kragtig genoeg is om tot nuwe insigte en benaderinge te lei nie (28:242).

\section{Die aarcle as wêreld van die mens}

Die benadering van ruimtelike differensiasie as doel eerder dan as middel het mettertyd dus verflou en in die plek daarvan het gekom, minstens wat die Amerikaanse geografiese skool betref, die opvatting dat die geografie as doel het 'n „studie wat wetenskaplike beskrywing van die aarde as die wêreld van die mens wil voorsien" (28: 242; $1: 435)$. Die opvatting wat dus reeds 'n halwe eeu gelede deur Barrows verkondig is, naamlik dat die geografie uitsluitend gemoeid is met die onderlinge betrekkinge tussen die mens en sy gekombineerde fisiese en biologiese omgewings, kry dus nou die erkenning wat dit aanvanklik nie geniet het nie $(2: 3 ; 1$ : 431). Tereg kan gesê word dat die geografie as beskrywing van die aarde een van die oudste, as wetenskap van die onderlinge verhouding tussen die mens en sy omgewing een van die jongste van die wetenskappe is $(6: 138)$.

Die pleidooi vir die insluiting van die fisiese mens as een van die faktore in die omgewing wat die geografie bestudeer, 
is nie die eerste keer deur Barrows uitgespreek nie en dit is ook nie 'n produk van Amerika nie. Immanuel Kant het reeds in die tweede helfte van die agtiende eeu nie alleen die mens ingesluit as een van die faktore van die aardbodem nie, maar hy het die mens ook beskou as een van die belangrikste agente wat verandering daarop aanbring (16:43). En in 1905 het Alfred Hettner verklaar dat sowel die mens as die natuur deel is van die karakter van 'n gebied en dat hulle inderdaad so nou saamgesnoer is dat die een nie van die ander geskei kan word nie $(15: 50)$.

Maar juis op hierdie terrein het die geograaf van die vroeë twintigste eeu deur beklemtoning van 'n teoretiese dichotomie tussen mens en omgewing vir hom 'n tydperk van verwarring en gebrek aan prestasie veroorsaak. Aan die een kant wou hy die mens en sy werke sien en aan die ander kant die natuur, en tussen die twee wou hy 'n ingewikkelde patroon ontdek van invloed wat deur die natuurlike omgewing op die mens uitgeoefen word. Aangevuur deur die intertydse opvatting dat die sogenaamde suiwer wetenskappe absolute wetmatigheid op hul onderskeie terreine kon ontdek, wou geograwe enersyds probeer bewys dat die mens op soortgelyke wyse beheer word deur natuurwette, dit wil sê, die wette van die omgewing waaruit die mens kunsmatig verwyder is. Daar is selfs oorgegaan tot ' $n$ soort personifikasie van die natuurlike omgewing met bewerings dat die natuur 'n plan het $(16: 62)$ of dat die aarde vir die mens take stel, sy gedagtes rig en oplossings vir die probleme aan hom fluister (25:1-5).

En hierteenoor is die standpunt gestel dat die natuur nie beheer uitoefen nie en dat die mens bloot deur die uitoefening van sy vrye wil kies tussen die moontlikhede wat die natuur hom bied.

Wat ook al die meriete van hierdie filosofiese standpunte is, die grondslag waarop albei berus, naamlik dat die mens afsydig staan van die natuurlike omgewing, het die geograaf in die situasie laat beland waar hy die natuur steeds as oorsaak en die werke van die mens steeds as gevolg moes beskou; hy het homself die reg ontneem om ook die werke van die mens as oorsaak te beskou, net asof dit enigsins moontlik is om in die bewoonde wêreld van vandag ' $n$ besliste skeiding te maak tussen dit wat oorspronklik en ongeskonde van die natuur is, en dit wat suiwer die resultaat van menslike optrede is $(15: 42)$. 
Die deurvoering van hierdie kunsmatige skeiding in die uitvoering van elke brokkie geografiese werk was onhoudbaar, hoewel dit vanselfsprekend geoorloof is by die bestudering van 'n spesifieke probleem net soos onderskeid gemaak kan word tussen die lewendige en die lewelose of die materiële en die nie-materiële verskynsels by die bestudering van spesifieke verhoudings $(15: 64)$.

\section{Totale biologiese realiteit}

Ook wat die posisie van die mens in die omgewing betref, het daar dus ' $n$ verskuiwing in die geografiese denke gekom. In hul omskrywing van die biogeografie verklaar Morgan en Moss dat dit probeer om tot ' $n$ waardering te kom van die totale biologiese realiteit, insluitende die mens self as essensiële komponent van die totaal-omgewing eerder as 'n buitestaande invloed (21:349),

Barrows se pleidooi in 1923 al vir die beskouing van die geografie as menslike ekologie was deel van hierdie strewe $(2: 3)$. Hoewel dit lank geduur het voordat hierdie oproep weerklank gevind het, word die ekologiese benadering vandag by vooraanstaande geograwe van baie lande aangetref. Só beskou S. V. Kalésnik die geografiese landskap as bestaande uit alle komponente wat só intiem met mekaar geassosieer is dat ' $n$ verandering in die een die ander vroeër of later sal affekteer. „Dit is 'n onwrikbare wet van die geografiese omgewing. Om dit te ignoreer, beteken om uiters ernstige gevolge uit te lok" (17:18).

Dit beteken nie dat die geografie by die aanvaarding van die ekologiese benadering sy fisiese sy wil afstaan nie. Eyre wys daarop dat die noodsaaklikheid vir die begrip van die uitwerking van fisiese verskynsels op faktore wat vir die organiese lewe belangrik is, vanselfsprekend is $(9: 374)$. Maar net soos die mens nie in isolasie beskou kan word nie, kan ook die fisiese verskynsels nie in isolasie beskou word nie: hulle maak ook deel uit van dieselfde geografiese omgewing wat sowel in sy totaliteit as in die verskillende onderlinge verwantskappe bestudeer moet word.

Ook hier blyk dat die beskouing van die landskap as ' $n$ hoogs geïntegreerde verskynsel nie so oorspronklik was toe dit die eerste keer in die twintigste eeu uitgespreek is nie. In die eerste helfte van die negentiende eeu het Ritter reeds 
gesê: „Die aarde is één; al sy dele is in onophoudelike aksie en reaksie op mekaar. Die aard is dus 'n eenheid, 'n organisme in homself; dit het sy eie wet van ontwikkeling, sy eie kosmiese lewe; dit kan nie in net een van sy samestellende dele bestudeer word nie" ( $27: 692)$. Maar vir Ritter met sy teleologiese beskouing was die insluiting van die mens as faktor in die omgewing ondenkbaar, omdat die aarde volgens sy beskouing spesifiek geskep was vir die ontwikkeling van die mens (15: 48v.) en die mens vir hom dus totaal buite die omgewing gestaan het.

Twee gedagtes wat nou met die ekologiese beskouing saamhang, is Mobius se opvatting van die biosenose ('n groep plante en diere wat op een plek saam leef) en Dahl se idee van die biotoop (wat die verdere gedagte bybring van die habitat waarin die besondere biosenose hom bevind). Hierop is Tansley se opvatting van die ekosisteem gegrond, naamlik die erkenning van die wederkerige verhouding tussen die hele kompleks van organismes wat as 'n sosiale eenheid saam leef, en die habitat $(21: 344 ; 28: 243)$. Dié ekosisteem word gekenmerk deur ' $n$ voortdurende en ingewikkelde reeks van transformasies van materie en energie onder die organismes, die laer lae van die atmosfeer en die oppervlak van die aardkors (21 : 344). Anders gestel, bestaan 'n ekosisteem uit bevolkings van lewende organismes en 'n kompleks van omgewingsfaktore waarin die organismes onderling op baie maniere in wisselwerking verkeer en waarin ' $n$ wederkerige uitwerking tussen die omgewing en die bevolkings bestaan $(3: 3)$.

\section{Mens-wêreld-ekosisteem}

In die lig daarvan dat die fisiese mens deur die geografie opgeneem is as faktor in die totale omgewing, neem die studieveld van die geografie, naamlik die bestudering van die aarde as tuiste van die mens, nou 'n nuwe betekenis aan. Die terrein van die geografie kan nou beskou word as die ingewikkelde mens-wêreld-ekosisteem wat oor die hele aarde strek. Hiermee word een van die tergendste probleme van die geografie, dié van afbakening, vir hom opgelos. Dic vak hou hom enersyds besig met die aardverskynsels en met die mens. Hy neem sy leerstof andersyds uit die bevindings van baie ander vakke. Die gevaar bestaan dus voortdurend dat geograwe hul des- 
kundige terrein kan verlaat en hulle begeef op die gebied van ander vakke. Benader hy egter sy probleem uit die oogpunt van die ekosisteem, is sy vakterrein skerp afgegrens van dié van die bioloë, plantkundiges en andere wat hul besondere sisteme onder andere ook uit die ruimtelike oogpunt bejeën; want die geograaf spits hom toe op die ruimtelike analise van dié ekosisteem waarvan die mens en sy kultuur die belangrikste deel uitmaak. Aan die ander kant bestudeer baie van die sosiale dissiplines weer die mensgemaakte omgewing, maar in sy beskouing van hierdie verskynsels laat die geografie anders as die ander die klem val op die ruimtelike benadering. Waar dit dus die sisteem is wat bestudeer word wat die geografiese veld onderskei van die fisiese en biologiese wetenskappe, is dit die ruimtelike perspektief wat dit weer onderskei van die sosiale wetenskappe $(3: 4)$.

Hier is dus een van die redes waarom die aanvaarding van die beginsel van die ekosisteem in geografiese werk nuwe vergesigte skep $(28: 243)$. Maar dit is nie die enigste rede waarom die opvatting geograwe aangryp nie. Feit is dat die eeuelange proses waarin die geografie telkens dele van sy studieveld afgestaan het aan nuwe vakke wat in daardie rigtings spesialiseer en waarin dit telkens weer nuwe studievelde betree het, aanleiding vir baie geograwe was om te vra wat die toekoms van die vak is $(2: 2)$. Enkele jare gelede nog moes Ackerman in sy presidentsrede voor die Vereniging van Amerikaanse Geograwe erken dat die bydrae van die geografie in die bykans verbysterende opmars van die wetenskap in die afgelope jare beskeie was. „Ons was nie in die voorhoede van die wetenskap nie", het hy gesê, en as redes daarvoor het hy die noue verbondenheid aangevoer wat die geografie in die eerste drie dekades van die huidige eeu met die geologie en die geskiedenis gehandhaaf het. Die gevolg daarvan was enersyds 'n oormatige beklemtoning van die geomorfologie en andersyds die vrugtelose getwis oor die determinisme en al sy nuanses $(1: 430)$.

In die wêreld waarin die fisika daarin geslaag het om die atoom te splits, waarin die mens aan die vooraand staan van ruimtereise na ander planete, waarin die mediese en sosiale wetenskappe meegehelp het om die wêreldbevolking elke 30 jaar te laat verdubbel en waarin die mens die diepte van sy blik in die sterrehemel nou reeds meet in terme van duisend miljoene ligjare, is hierdie bydrae van die geografie, indien 
dit sy enigste prestasie is, nie indrukwekkend nie.

Indien die geografie die trotse posisie wil bly handhaaf waarop dit uit hoofde van sy lang geskiedenis aanspraak kan maak, en indien dit as navorsingsdissipline erkenning wil hê in ' $n$ wêreldomgewing wat bykans onherkenbaar verander het van dié van ' $n$ skamele honderd jaar gelede, sal dit self aanpassings moet maak wat aansluit juis by dié veranderde omgewing wat dit as vername deel van sy studieveld aanvaar. Want die metodes wat gepas het by die omgewing van voor die wetenskaplike ontploffing kan beswaarlik nog toereikend wees in die omgewing van wat Mumford noem ons meganiese beskawing ( $22: 530)$.

\section{Kenmerke van die veranderde omgewing}

Ook kan die metodes wat ontstaan het in 'n tydperk van yl menslike bewoning van die aarde nie sonder meer aanvaar word as toereikend vir 'n tydvak waarin die beskikbare per capita-ruimte en die natuurlike hulpbronne elke drie dekades met minstens die helfte verminder nie. Dit is trouens nie die menslike getalle wat net styg nie: daar is ook 'n daadwerklike vermindering in die hulpbronne self. Die olie- en steenkoolvoorrade word met benouende snelheid uitgeput. Die oppervlakte onder woude het in die afgelope paar eeue gekrimp van 230 miljoen vierkante myl tot 128 miljoen. As gevolg van gronderosie het die bewerkte landerye van die aarde in die afgelope eeu met byna 'n kwart verminder, en waar daar oorspronklik gedink is dat die aarde se varswatervoorrade onuitputlik is, dui 'n onlangse Russiese berekening aan dat die jaarlikse voorraad net soos die beskikbare grondoppervlakte beperk is. In die moderne nywerheidsbeskawing neem die verbruik van hierdie voorraad nie alleen onrusbarend toe nie, maar groot hoeveelhede skoon water word ook daardeur besoedel $(17: 16)$.

Dit wil inderdaad voorkom asof 'n groot deel van die mensdom vandag in sy benadering tot die omgewing nog nie veel verder gevorder het as die stadium wat Sylvia Crowe negatief noem, naamlik waar die omgewing beskou word as 'n skuur wat geplunder moet word, 'n vyand wat onderwerp moet word nie $(5: 538)$. Daar word geteer op die kapitaal van die landskap, sy bome, sy vrugbaarheid en sy water, en dit kan nie as uitgeslote beskou word dat die mens as deel van die ekosis- 
teem sekere wanverhoudings ingebring het waarteen die ekosisteem op die lange duur nie bestand sal wees nie. Daar is die voorbeeld van die fisiese bevolkingsdruk op beperkte oppervlaktes; daar kan moontlik selfs onversoenbare menslike houdings wees, soos inhaligheid, die rykwordingsdrag, die verafgoding van die monteerbaanproses - alles wat as einddoelstellings gesien word en nie as hulpmiddele tot 'n hoër doel nie $(5: 541)$. En in die proses het die mens 'n skokkende verandering in sy omgewing aangebring.

Dit is ' $n$ onrusbarende feit dat die mens die enigste organisme is wat, as gevolg van sy tegnologiese prestasie, oor die vermoë beskik om die habitat waarvan hy vir sy voortbestaan afhanklik is, geheel en al te vernietig. En selfs waar dié vernietiging nie regstreeks en doelbewus geskied nie, is dit die prestasies van dieselfde tegnologie wat meebring dat die mens se stede oorstroom word deur intrekkers van die platteland, dat agterbuurtes vinniger ontstaan as wat hulle opgeruim kan word, dat verkeerskanale toegewurg word en dat selfs die lug wat ingeadem word, dik is van die afval van die uitvindsels van die tegnologiese era.

\section{Pogings om die ewewig te herstel}

Om die wantoestande wat spruit uit sy bewoning van die aarde te beheer, het die mens die ruimtelike beplanning as wapen aangegryp. Eintlik is dit geen nuwe metode nie: vyf millenniums en meer gelede is beplanning reeds toegepas in die rivierbeskawings van die "Vrugbare Sekelmaanstreek" (22: 73 ) en sedertdien oral waar groter groepe mense saam 'n bestaan moes maak op 'n terrein waar die een of ander natuurlike hulpbron beperk is ( $8: 54)$. Maar dit is eers in die moderne tyd waarin die nadelige gevolge van onewewigtige konsentrasies deur die tegnologie werklikheid geword het, dat ruimtelike beplanning op georganiseerde skaal as saak van nasionale beleid aangewend is om toestande te probeer verbeter $(8: 59)$.

Die besef van die ware omvang van die benodigde beplanning het egter stadig deurgedring. Die helder lig van die tegnologiese era het die mens tydelik verblind en oplossings vir probleme wat regstreeks die gevolg van tegnologiese vordering was, is gesoek by die tegnologie self (14:12). Die argitek, die landmeter, die regsgeleerde, die ingenieur, selfs die manne 
van die monteerbaan en die stootskraper is beskou as die potensiële helde wat deur hul onderskeie vernuftighede oplossings sou bring vir die probleme van die wanbalans $(8: 71)$.

Dit is eintlik eers seclert die jongste wêreldoorlog dat besef word dat die tegnologie nie die oplossing vir alle probleme het nie. Fraser Dowling toon bv. aan dat die ,alles verowerende tegnologiese mens wie se denke dieselfde karaktertrekke het as die stootskrapers wat gebruik is vir die kweek van grondbone in Tanganjika" uit die mode is, en dat daar nou ook geluister word na ekoloë (7).

\section{Verhouding tussen mens en omgewing}

Dit het lank geduur vir die beplanner om tot hierdie standpunt te kom, want selfs toe die besef deurgedring het dat die oorbevolking en agterbuurttoestande in die stad dikwels hul oorsprong in ontvolking en gebrekkige geleenthede op die platteland het en dat die streek as geheel benader moet word, is nog eers geprobeer om remedieë te vind deur middel van wat Duvenage probleemoplossing noem $(8: 258)$. Probleme is naamlik in isolasie gesien, met die gevolg dat oplossings wat vir die een probleem aangewend is, dikwels die oorsaak van verdere probleme op ander terreine was. Dit is maar eers in die onlangse tyd dat die ruimtelike beplanning "die verhouding van die mens tot sy omgewing en hulpbronne minstens van gelykwaardige belang beskou as die verhouding tussen mense onderling" (14:12, $18: 259)$. Die oogmerke van dif ruimtelike beplanning is dus ook nie langer om in die eerste plaas losstaande probleme op te los nie maar om, in dic woorde van Glikson, die verhouding tussen menslike en om. gewingsfaktore te reguleer ( $14: 9)$.

Net soos die geografie is die ruimtelike beplanning vandag dus primêr gemoeid met die aarde as woonplek van die mens.

\section{Wat die geografie kan aanbied}

Die vraag ontstaan dus wat die geografie kan aanbied in die nuwe opset waarin die mens en die bodem, m.a.w. die onderdele van die tweeledige studie-objek van die geografie, in voortdurende wisselwerking verkeer. Dié vraag het by baie geograwe opgekom, en daar kan met gerustheid verklaar word dat daar vandag 'n redelik algemene strewe bestaan om 
die vrug van die geografiese navorsing in die praktyk toegepas te sien, en om langs dié weg ewewig in die verhouding mensbodem te bewaar of te herstel. Só verklaar Stamp: „As die afgelope vyftig jaar bestee is aan die ontwikkeling van geografiese metodes van opname en analise, het die tyd sekerlik nou aangebreek om daardie metodes aan te wend vir die beter begrip en vertolking van sommige kenmerke van die wêreld van vandag" $(26: 10)$.

Kimble, van die Verenigde State, kom min of meer by dieselfde gedagte uit waar hy sê dat die geografie gemoeid is met al die ruimtelik gedifferensieerde dinge wat betrekking op die lewe van die mens het, op sy toekomstige welsyn nie minder as op sy huidige posisie nie $(18: 20)$.

In 'n ander pleidooi vir ' $n$ nuwe rigting in die geografie het 'n paneel van Amerikaanse geograwe vier jaar gelede ook 'n strewe na 'n drietal doelstellings geformuleer, naamlik eerstens na 'n wetenskapliker geografie - 'n matematiese, kwantitatiewe wetenskap geskoei op die bou van modelle en ingestel op die ontwikkeling van beginsels - tweedens na 'n meer toegepaste geografie met ' $n$ belangrike rol in die ruimtelike beplanning en derdens na 'n psigologiese geografie met ' $n$ toenemende belang in dinamies menslike uitings soos nasionale karakter en modale persoonlikheid (19:582).

Maar die probleem van noodsaaklike nuwe rigtings en die geleentheid om die navorsingsresultate toe te pas, is nie beperk tot die geograwe van die Westerse wêreld nie. By die funksie wat die viering van sy sestigste verjaarsdag gekenmerk het, het Gerasimov van die Sowjet-instituut van Geografie ook drie probleemgebiede vir die geografie afgebaken, waarvan die eerste en die derde onderskeidelik lui: „Die ontwikkeling van 'n teorie en die uitwerk van wetenskaplike programme vir 'n beplande transformasie van die natuur wat nodig is vir die doeltreffende gebruik van hulpbronne, die skepping van nuwe en die heropbou van bestaande territoriale produksiekomplekse.

„Die bestudering van nedersettingspatrone en van ontwikkeling van bewoonde gebiede onder verskillende geografiese omstandighede en die uitwerk van wetenskaplike programme van plaaslike gebiedsbeplanning met die oog op die skepping van gunstige toestande vir die lewe van die mens" (13:13).

Vir Gerasimov is die toekomstaak van die geografie dus 
die bestudering van probleme op so 'n wyse dat die bevinding van die studie in die praktyk toegepas kan word. Sy landgenoot, Kalésnik, bepleit weer dat die geografie hom moet toespits op dit wat vereis word deur die lewe. Hy som sy beskouings op met die verklaring dat geograwe dieper sal moet ingaan op die probleem van die wisselwerking tussen die natuur en die gemeenskap en dat hulle ' $n$ algemene teorie en metodologie sal moet uitwerk vir die doelbewuste transfor. masie van die natuur $(17: 19)$.

\section{Geografie en beplanning}

Die geografie, wat hom tradisioneel besig hou met die studie van die wisselwerking tussen die verskillende faktore van die omgewing, bevind hom op die tydstip van die hede dus by die beginpunt van die ruimtelike beplanning vir die toekomstige regulering van juis dieselfde wisselwerking, met die mens in albei gevalle as die vernaamste faktor. Die hede is dus die logiese punt van ontmoeting tussen die geografie en die nuwe beplanningswetenskap. Maar net soos die geografie vandag nie meer bereid is om op te hou by die tydstip van die hede nie, inderdaad sy blik vorentoe wil werp om daar praktiese toepassing te vind vir die lesse wat hy geleer het uit sy besondere benadering, net so kan die beplanning ook nie op die punt van die hede begin sonder om ook te let op wat voorheen was nie. Want soos Moolman aangedui het, aan die een kant spruit die doeleindes van beplanning uit die ideale vir die toekoms, maar aan die ander kant word dit gebore uit die probleme van die verlede $(20: 6)$. Ook beplanning moet sy studiemateriaal dus uit die verlede put $(11: 172)$.

Waar dit die ruimtelike perspektief is wat die geografie help om hom te onderskei van die sosiale wetenskappe, en waar dit sy klem op die mens in die ekosisteem is wat hom onderskei van die biologiese en fisiese wetenskappe, help hierdie maatstawe van onderskeiding die geografie nie in die begrensing van sy terrein teenoor die ruimtelike beplanning nie. Albei hierdie perspektiewe wat vir die geografie geld, geld eweseer vir die ruimtelike beplanning.

Is die geografie en die beplanning dan een? As antwoord op hierdie vraag is ' $n$ kategoriese ja of nee nie gewens nie. Dit sal aan die een kant vir die geografie, wat sy wortels het in die tyd voor Athene, meer as ontmoedigend wees as hy na 
al die jare van bestudering van die aarde as tuiste van die mens nou nog nie na vore kan tree met sekere vaste lesse vir die toekoms nie. Aan die ander kant loop die geografie deur ' $n$ te intieme koppeling met die praktiese gevaar om in ' $n$ filosofiese tweespalt te beland omdat dit as teoretiese wetenskap saam met ander wetenskappe soek na „die reëlmaat agter 'n verskeidenheid van gebeurtenisse", soos Ackerman dit stel ( 1 : 433), en die beskrywing van voorwerpe in hul individualiteit. Daarteenoor wil die ruimtelike beplanner nie soseer die huidige en die verlede ontdek en verklaar nie as om in die toekoms te bereik wat behoort te wees. In 'n gesprek met Benton McKaye het Patrick Geddes die onderskeid kernagtig gestel: „Geografie is 'n beskrywende wetenskap; dit vertel wat bestaan. Geotegniek is 'n toegepaste wetenskap; dit wys wat behoort te wees" (14:73). Die beplanning, of geotegniek, soos Geddes dit noem, gebruik dus normatiewe en nie empiriese premisse nie, en dit streef na die vervulling van oogmerke wat in die eerste instansie sosiaal gewens is in teenstelling tot die suiwer wetenskaplike oogmerke van die teoretiese wetenskap ( $4: 583$ ).

Maar aan die ander kant sal dit minder as regverdig teenoor die ruimtelike beplanning wees as voorgegee word dat dit nie ook beslis nuttige aanwending het vir die reëlmaat agter die verskeidenheid van gebeurtenisse in die verlede om sy sosiale oogmerke vir die toekoms daarvolgens te formuleer en te probeer verwesenlik nie. Omdat dit juis dié reëlmaat is wat die geografie probeer vasstel, beteken dit dat die geografie met sy besondere benadering werk kan lewer waarsonder die ruimtelike beplanner nie kan klaarkom nie (11:13).

Dit word op ondubbelsinnige wyse deur Glikson erken waar hy sê dat die beskrywing van die landskap as die kompleks van natuurlike, sosiale en ekonomiese verhoudings binne die streek die onderwerp van geografiese opname is; dat die hernuwing van die kultuurlandskap die oogmerk van dic geotegniek is waardeur geprobeer word om te verwesenlik wat behoort te wees, en dat die sintetiese siening van die ou landskap 'n voorwaarde is vir die skepping van die nuwe landskap (14: 76). En dit is trouens die geografie alleen onder al die wetenskappe wat die verhouding tussen die mens en sy totale omgewing met die daaruit voortvloeiende probleme as geheel en as eenheid benader $(26: 9 ; 8: 257)$. Dit is dus net die geografie wat hierdie materiaal aan die beplanner kan voorsien. 


\section{Teenkoppeling}

Aan die ander kant sal die uitvoering van die beplanner se werk weer 'n nuutsoortige omgewing skep wat in die toekoms die studieveld van die geografie gaan word. Só gesien, ontstaan daar dus 'n kringloop, 'n soort teenkoppeling, tussen die geografie en die ruimtelike beplanning, waarin die een aanvullend en trouens onmisbaar vir die ander is sonder dat wetenskaplike vooruitgang in die geografic as wetenskap an die gevaar blootgestel hoef te word wat spruit uit die utilitaristiese sienswyse waarteen Hartshorne waarsku (16:36).

Maar vir die uitvoering van hierdie wedersydse aanvulling is dit nodig dat die geografie sy beskouings en sy metodes moet versoen met die eise van die hede. Onveranderlikheid te midde van 'n mens-bodem-verhouding wat voortdurend in al sy samestellende dele verander, sal vir die geografie stagnasie en moontlik selfs ondergang beteken. Aan die ander kant kan tydige aanpassing soos dikwels in die verlede aangepas is by veranderde omstandighede, die geografie weer aan die voorpunt van wetenskaplike navorsing stel deur middel van die bydrae wat hy in sy totaliteitsiening kan lewer tot die oplossing van die dringende probleme van die mensdom as geheel.

\section{Aard van aanpassing}

Daardie aanpassing sal myns insiens in hoofsaak bestaan uit dic aanvaarding en praktiese uitvoering van die begrip van die ekosisteem waarvan die mens die vernaamste bestanddeel is. Dit is nie soseer deur die streeksbegrip en die streeksmetode, soos Fair bepleit $(10: 18)$, dat die geografie sy bydrae kan lewer tot die oplossing van die probleme van die mens-bodem-verhouding nie, want die ruimtelike beplanning het die streeksbegrip lankal deel van sy eie werkmetode gemaak en selfs 'n nuwe dimensie daaraan toegevoeg (12:19; 24).

Ook is die tradisionele geografiese kaart sonder meer nie langer vir die beplanner aanvaarbaar nie, en daar word reeds gedroom van 'n nuwe soort kaart van die sogenaamde superruimte van die beplanner, waarin ' $n$ hoër peil van abstraksie bereik sal word as in die kaart soos die geograaf dit ken (12 : 18). Op hierdie terrein kan die geograaf dus hoogstens 'n gebrekkige bydrae lewer, want sy aansluiting by die praktiese 
uitvoering van die resultate van sy studie is slegs gedeeltelik.

Dit is egter by die ekologiese beskouing, en by die opvatting van die ekosisteem waarvan die mens die vernaamste deel uitmaak, dat die aansluiting van die geografie by die ruimtelike beplanning volkome is, omdat hierdie begrip eie is aan albei. Nie alleen bied die opvatting van die ekosisteem aansluiting by die ruimtelike beplanning nie, maar ook by talryke ander wetenskappe indien die bestudering daarvan gepaard gaan, soos dit met min moeite kan geskied, met die aanwending van die informasieteorie en die moontlikhede wat die sibernetika bied (28:243; $1: 437)$. Sodanige aanwending het trouens al met groot sukses geskied (23).

Dat dit aan die geograaf van die toekoms veel hoër eise sal stel wat veral sy kennis van die wiskunde betref, is van. selfsprekend, en Ackerman waarsku selfs dat die tyd nie meer ver is nie dat 'n geograaf sonder opleiding in die wiskunde onmagtig sal wees om op hoogte van sy vak te bly $(1: 432)$. Maar daar kan aan die ander kant nie verwag word dat 'n dissipline in die kontemporêre tydperk van ongeëwenaarde wetenskaplike vooruitgang aan die voorpunt van die navorsingsfront kan bly as sy beoefenaars nie bereid is om die nodige opofferinge daarvoor te doen nie.

In die ekologiese benadering en die beginsel van die ekosisteem het die geografie van die sewende dekade van die twintigste eeu dus sowel sy uitdaging as sy geleentheid. Daardeur kan dit nie net sy eie voortbestaan regverdig en verseker nie, maar ook dié van die mens wat 'n onmisbare deel van sy studieveld uitmaak. Omdat dit deel van die mens se wese is om te wil voortbestaan, en omdat die ekologiese benadering ' $n$ voorwaarde vir sy voortbestaan geword het, moet aanvaar word dat die bestudering van die ekosisteem waarvan die mens deel uitmaak, wel onderneem sal word. Die vraag is slegs of dié studie deur middel van 'n nuwe benadering gedoen sal word deur die geografie, of dan wel deur 'n ander wetenskap. Dit hang van diegene af wat in die diens van die vak staan of die uitdaging vir die geografie vir hom 'n nuwe tydperk van prestasie sal inlui, of sy wegkwyning en permanente relegering tot die posisie van ' $n$ minderwaardige wetenskap.

P.U. vir C.H.O.

F. J. Potgieter. 


\section{BIBLIOGRAFIE}

1. Edward A. Ackerman: Where is a research frontier? (A.A.A.G, vol. 53, nr. 4, pp. 429-440, Dec. 1963).

2. Harlan H. Barrows: Geography as human ecology. (A A A.G., vol XIII, nr. 1, pp. 1-14).

3. Brian J. L. Berry: Approaches to regional analysis: a synthesis. (A A.A.G., vol. 54, nr. 1, pp. 2-11).

4. Sherwin $H$. Cooper: Defining the planning-geography relationship (A.A.A.G., vol. 53 , nr. 4 , p. 583 ).

5. Sylvia Crowe: Civilization and landscape (Smithsonian Institution Report for the year ended June 30, 1962).

6. R. E. Dickinson and 0. J. R. Howarth: The making of gcography (Oxford, 1933).

7. F. Fraser Dowling: The unity of ecology. (Advancement of science, Nov. 1963).

8. J. P. Duvenage: Geografie en geotegniek. (Ongepubliseerde proef skrif).

9. S. R. Eyre: Determinism and the ecological approach to geography (Geography, Nov. 1964, p. 369).

10. J. T. D. Fair: Geography and physical planning. (S.A. Geographical Journal, Dec. 1956).

11. T. W. Freeman: Geography and planning. (London, 1953).

12. John Friedman and William Alonso: Regional development and planning - a reader. (Cambridge, Mass, 1965).

13. I. P. Gerasimov: The past and the future of geography. (Soviet geography, vol. VII, nr. 7, pp. 3-15).

14. Artur Glikson: Regional planning and development. (I.eiden, 1955)

15. Richard Hartshorne: The nature of geography. (Lancaster, Penna., 1946).

16. Richard Hartshorne: Perspective on the nature of geography (Chicago, 1959).

17. S. V. Kalésnik: Geography today. (Soviet geography, vol. VII, nr. 7, pp. 15-19).

18. George H. T. Kimble: The United States Geography Project of the Twentieth Century Fund. (A.A.A.G, vol. 54, nr. 1, pp. 19-23).

19. Melvin F. Levine: New directions in geography - applied geography (A.A.A.G., vol. 53, nr. 4, p. 583)

20. J. H. Moolman: Fisiese beplanning en die universiteite. (Medede lings van die Universiteit van Suid-Afrika).

21. W. B. Morgan and R. P. Moss: Geography and ecology: the concept of the community and its relationship to environment. (A A A.G., vol. 55 , nr. 2, pp. 339-350).

22. Lewis Mumford: The city in history - its origins, its transformations and its prospects. (London, 1963).

23. Bernard C. Patten: An introduction to the cybernetics of the ecosystem: the trophic-dynamic aspect. (Ecology, vol. 40, 1959, pp. 221, 231).

24. Francois Perroux: Economic space: theory and application. (Quar terly Journal of economics, vol. 64, Feb. 1950). 
25. E. C. Semple: Influences of geographic environnent. (New York, 1911).

26. L. Dudley Stamp: Applied geography. (Bungay, 1964).

27. D. R. Stoddart: Darwin's impact on geography. (A.A.A G, vol. 56, nr. 4, pp. 683-698).

28. D. R. Stoddart: Geography and the ecological approach - the ecosystem as a geographic principle and mcthod. (Gcography, vol. 1, nr. 3, pp. 242-251). 